\title{
ESTIMATION OF THE EXPLOSIVE MASS BASED ON THE SURFACE EXPLOSION CRATER ON ASPHALT
}

\author{
Ivana D. Bjelovuk, Slobodan Jaramaz, Predrag Elek, Dejan Micković, Lazar Kričak
}

Preliminary notes

In the course of court trials and for the purpose of legal proceedings, forensic engineers often produce estimations of the explosive mass based on the explosion effect using empirical formulas. This paper describes experimental surface explosions of variable mass of known explosive charge on the asphalt with the objective to make correlations between causes and consequences of an explosion. Dimensions of the resulting craters were measured and an overview of experimental tests and reliability of nine equations for calculating the mass of explosive based on the dimensions of the craters is given. The asphalt surfaces were chosen since the highest number of explosions, which are the results of terrorist or some other criminal acts, occur in urban conditions where asphalt is the dominant surface. Based on the given overview it is possible to give an evaluation of equation's reliability for explosive mass less than $1 \mathrm{~kg}$. The paper also gives the proposition of the new equations for preliminary estimation of explosive charge mass based on volume of the crater resulting from the surface explosion on asphalt.

Keywords: asphalt; crater; explosive mass; forensic engineering; surface explosion

Procjena mase eksploziva na temelju kratera nakon površinske eksplozije na asfaltu

Prethodno priopćenje

U tijeku suđenja, a za potrebe sudskih postupaka, forenzički inženjeri često proizvode procjene ksplozivne mase na temelju učinka eksplozije pomoću empirijskih formula. Ovaj članak opisuje eksperimentalne površinske eksplozije na asfaltu sa promjenjivom masom poznatog eksplozivnog naboja s ciljem uspostavljanja korelacije između uzroka i posljedica eksplozije. Dimenzije proizišlih kratera su mjerene i dan je pregled eksperimentalnih ispitivanja i pouzdanost devet jednadžbi za izračunavanje mase eksploziva na temelju dimenzije kratera. Obzirom da se najveći broj eksplozija, koje su posljedica terorističkih ili nekih drugih kaznenih djela, dogadja u urbanim uvjetima gdje je asfalt dominantna površina izabran je asfalt za ispitivanje. Na temelju danog pregleda je moguće dati procjenu pouzdanosti jednadžbi za eksplozivne naboje manje od $1 \mathrm{~kg}$. Rad također daje prijedlog novih jednadžbi za preliminarne procjene mase eksplozivnog punjenja na temelju volumena kratera kao posljedice eksplozije na površini asfalta.

Ključne riječi: asfalt; krater; forenzični inženjering; masa eksploziva; površinska eksplozija

\section{Introduction}

There are a large number of planted explosions throughout the world (terrorist purposes, intimidation, intention to assassinate a person, or for the purpose of overcoming possible obstacles during an act of theft, or to cause public danger, etc.). It is therefore important to focus on the analyses showing how reliable the estimations of the mass of planted explosive are, since these analyses are produced for the court by forensic engineers. Namely, there are visible evidences on the explosion site and the cause of the explosion can be determined. The typical evidences of an explosion of a lethal device are the formation of a crater and some other damages, different in shape and size, as well as parts of the explosive device $[10,1,2]$. Establishing the exact mass of explosive used is important for the court because it can prove the intention of the perpetrator of the criminal act. Higher values of explosive mass are indicative of the intention of causing a larger number of casualties and greater material damage. Many authors, who deal with the effects of explosions, emphasize the importance of studying the effects of an explosion to the environment [5, $6,11,16]$. When an explosion takes place different forensic experts will go to the crime scene in order to perform an investigation in accordance with the court order. At first it cannot be determined with certainty what kind of the explosion that was (whether it was a chemical explosion or not). The answer to that and all other questions about the explosion will be given by a registered court's expert who, with the authority of his knowledge, skills and experience offers his expertise and opinion about the determined facts [3]. Investigation of an explosion site can include the engagement of experts from many areas since it is a phenomenon calling for a multidisciplinary approach. Thus, the examination of the explosion cause can be made by chemical engineering experts who, based on the samples taken from the explosion site and with the use of appropriate analytical methods, can give information about the type of the explosive used; forensic engineers can give information about the mass of the explosive used based on the damage caused by the explosion, type of the used explosive device, the method of initiation, and, finally, about material damage; forensic pathologists can provide information about the injuries sustained by the victims of the explosion; forensic biologists - experts in genetics can give information about possible DNA profile and fingerprint experts can give information about possible fingerprints left by the perpetrator, and the like.

This paper gives the overview of existing nine empirical equations. Also, we used experimental modelling technique for the proposition of the new equations for preliminary estimation of explosive charge mass based on volume of the crater resulting from the surface explosion on asphalt that can be used on the scene.

\section{Crater as the effect of an explosion to the environment}

Many evidences resulting as consequences of an explosion can be scattered over a large area and they are also inconstant, while the damages have permanent nature. The damages that emerge from some surface 
explosion of condensed explosive charge may occur as a variety of different mechanical damages with the obligatory characteristic evidence - the crater, which represents the centre of the explosion and the place where the explosive device was planted $[4,5]$. When it comes to the definition and terminology in the crater formation there is some confusion among the researches. This refers to the definition of the border line of the crater and natural structure, as well as to what is meant by the size of the crater [17].The true crater is limited by the area that emerged after the cleaning of pieces of the surface that went back to the crater after having been thrown out by the explosion. In this paper, the dimensions of the crater are adopted in accordance with Cooper [4]. The crater emerges as the consequence of the brisance effect of an explosion to its immediate surroundings [6]. In case of an explosion on the soil surface or just above the soil surface a pressure wave is created that compresses the surrounding area. The explosive wave spreads through the air and through the surface - in this case that surface is asphalt [12]. High explosives, such as TNT, PETN and hexogen leave visible traces in the form of blackening in the centre of an explosion because of the presence of carbon in the products of decomposition due to the contents of organic components and their negative oxygen balance [8]. Craters can be the source of fragments of the device and the explosive residues also. Evidences that are secured from an explosion site are then examined in the scientific or forensic engineering laboratory [1]. The forensic expert gives answers to the following questions: What is the cause of the explosion? What explosive was used? What was the mass of the explosive used? How was the explosive initiated? Who planted the explosive device? etc. With the examination of the received material and the documentation, the expert determines the type of the device, method of initiation, etc., and based on the crater dimensions, type of soil and damages in the surrounding area, the expert calculates the mass of the used explosive. The existence of a crater at the site of an explosion is important for the forensics because it offers possibilities to estimate the mass of the explosive that was used for some concrete explosion. It has so far been a widespread practice to determine the mass of used explosive based on the literature data and empirical equations for calculation, but the results obtained in this way have not always been reliable.

Some of the authors emphasize the low availability of literature about the examination of explosions at ground level and mechanisms of the crater formation [11]. The starting point is the hypothesis that the crater volume is directly proportional to the mass of the explosive charge. Relevant literature offers equations for the calculation of the mass of an explosive $M_{\mathrm{e}}$ based on the dimensions of the crater in the case of the explosion at ground level. "Due to the extreme complexities of the phenomena in dynamic fracture and fragmentation, the majority of blasting models today are based on empirical or semiempirical formulas." [13].

Within the forensic practice in the Republic of Serbia for explosive mass $M_{\mathrm{e}}$ estimation on the explosion site forensic engineers commonly use: Boreskov's, Vlasov's, Pokrovskii's, Kinney's and Cook's equations and they are shown as from Eqs. (1) to (5). Also, one can find the Eqs.
$(6) \div(9)$ in literature $[5,6,7,9,12,14]$. These equations are applicable for different sorts of soil.

$M_{\mathrm{e}}=38 k h^{3}\left(0,4+0,6 n^{3}\right)$,

where $M_{\mathrm{e}}(\mathrm{kg})$ is the mass of explosive used, $k$ is the coefficient depending on the sort of explosive charge, $h$ (m) is the depth of the crater, $r(\mathrm{~m})$ is the radius of the crater and $n=r / h$ is the ratio of the crater measurement.

$M_{\mathrm{e}}=\left(2 \pi \rho u r^{3}\right) / 100$,

where $\rho\left(\mathrm{kg} / \mathrm{m}^{3}\right)$ is the density of the asphalt and $u$ is the critical velocity needed for smashing the surroundings and $r(\mathrm{~m})$ is the radius of the crater.

$M_{\mathrm{e}}=0,02 r^{3} \rho_{\mathrm{e}}$

where $\rho_{\mathrm{e}}\left(\mathrm{kg} / \mathrm{m}^{3}\right)$ is the density of used explosive and $r$ $(\mathrm{m})$ is the radius of the crater.

$M_{\mathrm{e}}=0,032 r^{3}$ (in $\left.\mathrm{g}\right)$,

where $r(\mathrm{~cm})$ is the radius of the crater

$M_{e}=0,132 k\left(h r^{2}\right)^{0,877} \quad($ in $\mathrm{g})$,

where $k$ is coefficient, $r(\mathrm{~cm})$ is the radius of the crater and $h(\mathrm{~cm})$ is the depth of the crater.

Merrifield gives the relation between the radius of the crater $r(\mathrm{~m})$ and the mass of explosive used $M(\mathrm{~kg})$

$r=k M^{0,33}$,

where $M(\mathrm{~kg})$ is the mass of explosive used (expressed in TNT equivalent), $k$ is coefficient depending on soil surface $(k=0,2$ for very hard soil surface and $k=0,7$ for very soft soil surface) [14].

Szuladzinsky gives the relation between the mass of explosive used $M(\mathrm{~kg})$ and crater diameter $d(\mathrm{~m})$

$M_{\mathrm{e}}=p_{2} d^{2}+p_{1} d+p_{0}$,

where $M_{\mathrm{e}}(\mathrm{kg})$ is the mass of explosive used, $d(\mathrm{~m})$ is the diameter of the crater and $p_{0}, p_{1}, p_{2}$ are coefficients depending on surface [5].

Jaramaz quotes that radius of destruction zone $R_{\mathrm{d}}(\mathrm{m})$ can be calculated from the Eq. $R_{\mathrm{d}}=k_{\mathrm{d}} M_{\mathrm{e}}^{1 / 3}[6]$. After its transformation one can calculate the mass of the explosive used $M_{\mathrm{e}}(\mathrm{kg})$ from:

$M_{\mathrm{e}}=k_{\mathrm{d}}^{-3}\left(r^{2}+h^{2}\right)^{3 / 2}$,

where $k_{\mathrm{d}}$ is coefficient which depends on soil surface, $r$ (m) is the radius of the crater and $h(\mathrm{~m})$ is the crater depth.

Luccioni and Ambrosini propose that "...crater diameter can be approximately simulated as a linear function of $W^{1 / 4} \ldots$.. Authors suggested equation for predicting crater dimensions ( $D$ in $\mathrm{m}$ ) based on the mass of explosive used $\left(D=0,834 W^{1 / 4}\right.$, where $W$ (in $\mathrm{kg}$ ) is explosive mass), which has been tested for explosive charges greater than $1000 \mathrm{~kg}$ [15].This equation can be 
used for estimation of the mass of explosive based on crater dimensions and after its transformation it will be as follows:

$M_{e}=2,067 D^{4}$

where $M_{\mathrm{e}}(\mathrm{kg})$ is the mass of explosive used and $D(\mathrm{~m})$ is the diameter of the crater.

All these equations except (3) are applicable for the calculation of TNT mass with the multiplication with correction factor for the type of explosive that has been used.

The correlation between the dimensions of crater and mass of the used explosive is also given in the computer program Crater Sizes from Explosions and Impacts [18] by Holsapple, which was designed for the surfaces that have lots of characteristics different from characteristics of asphalt. Also, this program was made for the explosive charges of large mass. Because of the mentioned reasons, experimental data were not checked through this program.

\section{Experimental examinations of the effects of some high explosives on the asphalt surface - material and method}

Experiments are focused on the detonation of known explosives (known chemical and physical characteristics) on the asphalt surface. The objective of the experiments is to create a correlation between the type and mass of used explosive and the damage on the surface that emerged after detonation. Also, the objective of this work is to improve the forensic investigation of an explosion site - to estimate more precise value of the explosive mass in cases when the surface explosion was on asphalt. Since the forensic practice of the Republic of Serbia indicates that most commonly used high explosives are TNT, PETN and amoneks1, these explosives were examined in the experiment. Standard TNT charges with the mass of $0,1 \mathrm{~kg}$ and of $0,2 \mathrm{~kg}$ and their combinations, plastic explosive PETN, with the mass of $0,5 \mathrm{~kg}$ and prepared smaller explosive charges of $0,1 \mathrm{~kg}$ and of $0,25 \mathrm{~kg}$ were taken for the samples of high military explosives. Amoneks1 is commercial explosive (mixture of ammonium nitrate $45 \%$, TNT-30\%, Aluminum $23 \%$ and woodflour $2 \%$ ). It was used in its original package of $1 \mathrm{~kg}$ and in prepared charges of $0,1 \mathrm{~kg}, 0,2 \mathrm{~kg}$ and of 0,5 $\mathrm{kg}$. Explosive charges that are used in experimental explosions are presented in Figs. 1, 2 and 3. The characteristics of explosive used are given in Tab. 1.

The explosive charge was placed horizontally on the surface. Initiation of the explosive was carried out with the use of blasting cap (Fig. 4). The initiation was done by side.

Table 1 Characteristics of the explosives used in the experiments

\begin{tabular}{|l|c|c|c|}
\hline Explosive characteristic & TNT & PETN & Amoneks1 \\
\hline Chemical formula & $\mathrm{C}_{6} \mathrm{H}_{2}\left(\mathrm{NO}_{2}\right)_{3} \mathrm{CH}_{3}$ & $\mathrm{C}\left(\mathrm{CH}_{2} \mathrm{ONO}_{2}\right)_{4}$ & - \\
\hline Molecular weight & 227 & 316 & - \\
\hline Density $\rho_{\mathrm{e}}\left(\mathrm{kg} / \mathrm{m}^{3}\right)$ & 1600 & 1760 & 1060 \\
\hline Oxygen balance $(\%)$ & $-73,9$ & $-10,1$ & 0,24 \\
\hline Detonation velocity $(\mathrm{m} / \mathrm{s})$ & 6900 & 8400 & 4200 \\
\hline Explosion heat $Q_{\mathrm{e}}(\mathrm{kJ} / \mathrm{kg})$ & 4310 & 5860 & 4248 \\
\hline Explosion temperature $(\mathrm{K})$ & 3370 & 4500 & 2450 \\
\hline Deflagration temperature $\left({ }^{\circ} \mathrm{C}\right)$ & 300 & 210 & 248 \\
\hline
\end{tabular}

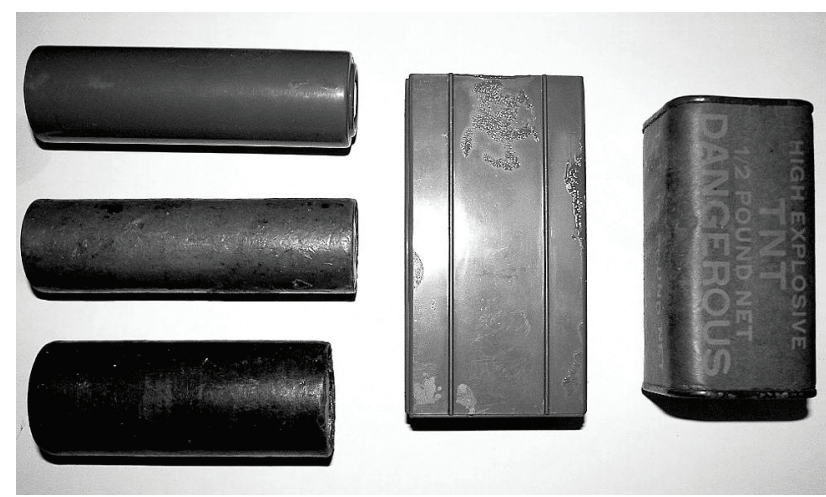

Figure 1 TNT charges used in experiments

The experimental explosions were done on the asphalt surface that was of good quality without visible damages in the form of holes, cracks, etc. Asphalt was made by compression of previously prepared mixture of gravel, mineral powder and bitumen. Asphalt obtains its physical and chemical characteristics after being pressed with a roller compression. When mixing mineral substances with bitumen, complex physical and chemical processes take place and their nature depends on the properties of created materials. The reaction between the binder and mineral material determines the properties of asphalt that change as the outside temperature changes. At the temperature below $0{ }^{\circ} \mathrm{C}$ asphalt is an elastic material while at the temperatures above $0{ }^{\circ} \mathrm{C}$ asphalt behaves like viscous-plastic material. All the experiments were done at the outside temperature of $20{ }^{\circ} \mathrm{C}$. The asphalt that was used for the experiment had the compressive strength of $1,47 \mathrm{MN} / \mathrm{m}^{2}$ and density $2000 \mathrm{~kg} / \mathrm{m}^{3}$. Fine-grained asphalt surface was used, i.e. mineral grains in asphalt mixture had the coarseness up to $15 \mathrm{~mm}$. The thickness of the asphalt pad used in experimental explosions was $80 \mathrm{~mm}$.

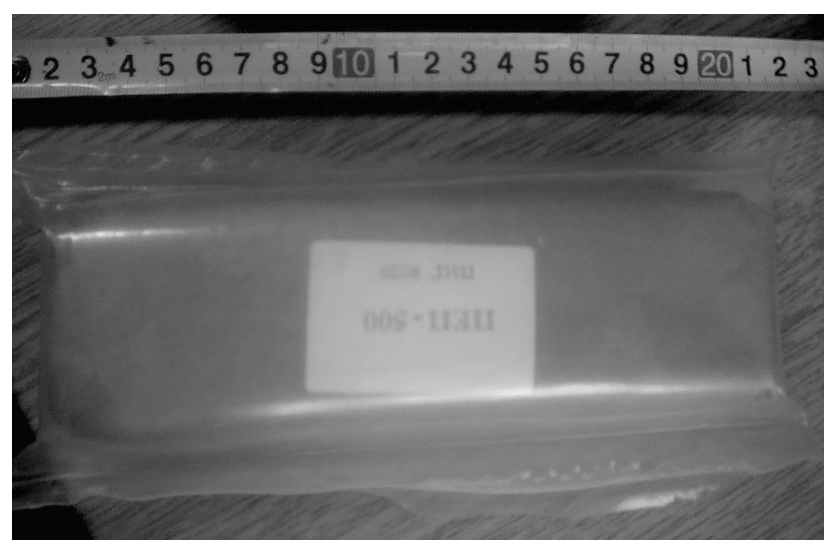

Figure 2 PETN charge used in experiments 


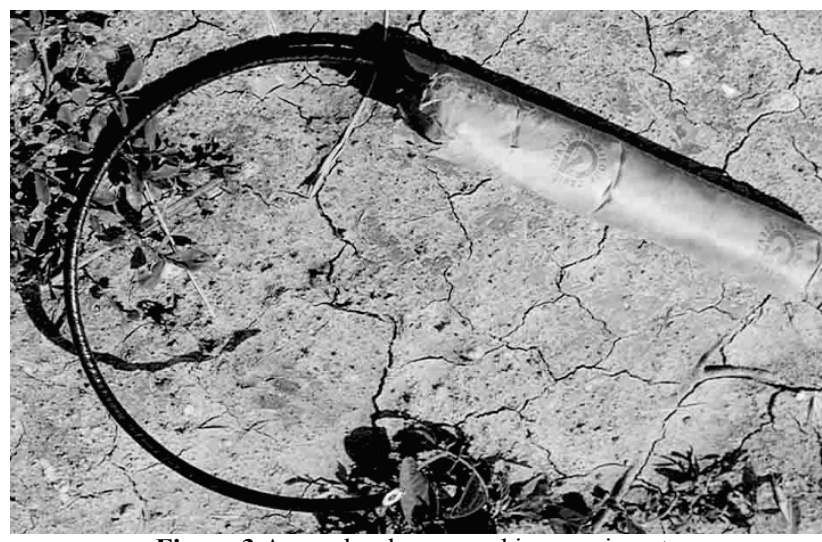

Figure 3 Amoneks charge used in experiments

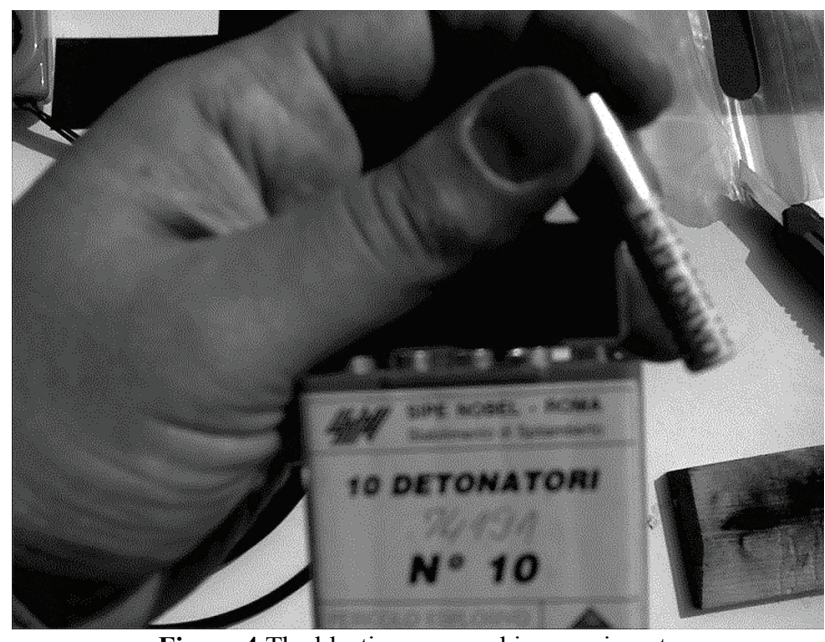

Figure 4 The blasting cap used in experiments

After the detonation damages emerged on the surface in the form of the crater that was examined in details, cleaned and measured (length $-a$, width $-b$ and depth $-h$ ) with conventional metric tape (the error of measurements is $0,001 \mathrm{~m})$. The crater volume was calculated as that of a cone with ellipse base $(V=a b h \pi / 12$, where $a$ and $b$ are ellipse's axes and $h$ is crater depth). The crater diameter was calculated as $(a+b) / 2$ and the crater radius was calculated as $(a+b) / 4$.

\section{Results and discussion}

After experimental detonations of TNT, PETN and amoneks1, damages in the forms of craters have emerged on the asphalt surface. The existence of the crater on the site of an explosion is the proof that the cause of the explosion was the explosive charge. The importance of the crater is great since based on its dimensions we can estimate the mass of explosive used. That information is important for the court because it can be connected with the intention of the perpetrator.

The experimental explosions were used to determine that the dimensions of craters primarily depend on the explosive mass used for the explosion, which confirmed the starting hypothesis. In this case the size of the crater depends, besides the mass of the used explosive, on the type of explosive. So, the damage to the surface was the most extensive when PETN was used, and this was followed by TNT and finally amoneks1, when the quantities of the said explosives were exactly the same. The surface explosions of Amoneks1, TNT and PETN showed a direct dependence of the explosive mass and the crater volume. The results of experimental explosions were given in Tab. 2 .

Table 2The results of experimental explosions

\begin{tabular}{|c|c|c|c|}
\hline $\begin{array}{c}\text { Explosive charge } \\
\text { mass }(\mathrm{kg}) \text { and its } \\
\text { dimensions }(\mathrm{m})\end{array}$ & $\begin{array}{c}\text { Contact } \\
\text { area } \\
\left(\mathrm{m}^{2}\right)\end{array}$ & $\begin{array}{c}\text { Dimensions of } \\
\text { the crater }(\mathrm{m})\end{array}$ & $\begin{array}{c}\text { The crater } \\
\text { volume } V_{\mathrm{k}} \\
\left(\mathrm{m}^{3}\right)\end{array}$ \\
\hline $\begin{array}{c}\text { Amoneks1 }(0,100) \\
\varnothing 0,028 \times 0,155\end{array}$ & 0,00434 & $0,20 \times 0,08 \times 0,012$ & 0,0000502 \\
\hline $\begin{array}{c}\text { Amoneks1 }(0,200) \\
2(\varnothing 0,028 \times 0,155)\end{array}$ & 0,00434 & $0,20 \times 0,11 \times 0,015$ & 0,0000864 \\
\hline $\begin{array}{c}\text { Amoneks } 1(0,500) \\
\varnothing 0,050 \times 0,180\end{array}$ & 0,009 & $0,28 \times 0,20 \times 0,05$ & 0,000733 \\
\hline $\begin{array}{c}\mathrm{TNT}(0,100) \\
\varnothing 0,33 \times 0,108\end{array}$ & 0,3564 & $0,14 \times 0,13 \times 0,02$ & 0,0000952 \\
\hline $\begin{array}{c}\mathrm{TNT}(0,200) \\
0,100 \times 0,050 \times 0,025\end{array}$ & 0,005 & $0,26 \times 0,20 \times 0,055$ & 0,0007487 \\
\hline $\begin{array}{c}\mathrm{TNT} 0,400 \\
0,100 \times 0,050 \times 0,050\end{array}$ & 0,005 & $0,25 \times 0,21 \times 0,055$ & 0,0007559 \\
\hline $\begin{array}{c}\text { PETN }(0,100) \\
\varnothing 0,020 \times 0,140\end{array}$ & 0,0028 & $0,21 \times 0,20 \times 0,034$ & 0,000374 \\
\hline $\begin{array}{c}\text { PETN }(0,250) \\
0,080 \times 0,035 \times 0,025\end{array}$ & 0,0028 & $0,40 \times 0,30 \times 0,07$ & 0,00219 \\
\hline $\begin{array}{c}\text { PETN }(0,500) \\
0,150 \times 0,060 \times 0,040\end{array}$ & 0,009 & $0,38 \times 0,38 \times 0,09$ & 0,003402 \\
\hline
\end{tabular}

Experimental explosions confirmed Livingston crater theory (If ratio between the charge length and the charge width is not higher than six the mechanism of crater formation is similar as in explosion of spherical charge). The shape of the explosive charge has a big influence on the shape of the crater base - elongated charges make elongated craters. The way in which the explosive charge was placed i.e. the size of the contact area also had the influence on the shape and dimensions of the crater, which means that if the explosive is placed horizontally the crater will be wider and shallower and vice versa. Horizontally placed charges will result in elliptic craters and vertically placed charges will result in circular craters. It can be noticed that the contact area between the explosive charge and the asphalt surface has the influence on the shape of the crater base. Namely, for the same value of the contact area approximately the same values of the crater bases will be obtained, while the larger masses of explosive will result in craters of larger volume. The surface explosions showed a direct dependence of explosive mass and the contact area in this work.

The place of explosive initiation also had the influence on the shape and dimension of the crater. So, for example, if the horizontally placed charge was initiated on one side, the crater will be a bit deeper on that side than on the other side. This is especially important from the forensic point of view because that is the part of the crater where one has to search for the residues of the initiation material.

If we make the approximation of the function with the method of the smallest deviation squares, the dependence of the used explosive mass from the crater volume $V_{k}\left(\mathrm{~m}^{3}\right)$ would be as follows:

$M_{\mathrm{e}}=10,65 V_{\mathrm{k}}^{0,504}$, 
where $M_{\mathrm{e}}(\mathrm{kg})$ is the mass of explosive used (TNT equivalent) and $V_{\mathrm{k}}\left(\mathrm{m}^{3}\right)$ is the crater volume.

The dependences of experimental $m_{\mathrm{e}}\left(V_{\mathrm{k}}\right)$ and calculated $M_{\mathrm{e}}\left(V_{\mathrm{k}}\right)$ explosive mass and crater volume are shown in Fig. 5.

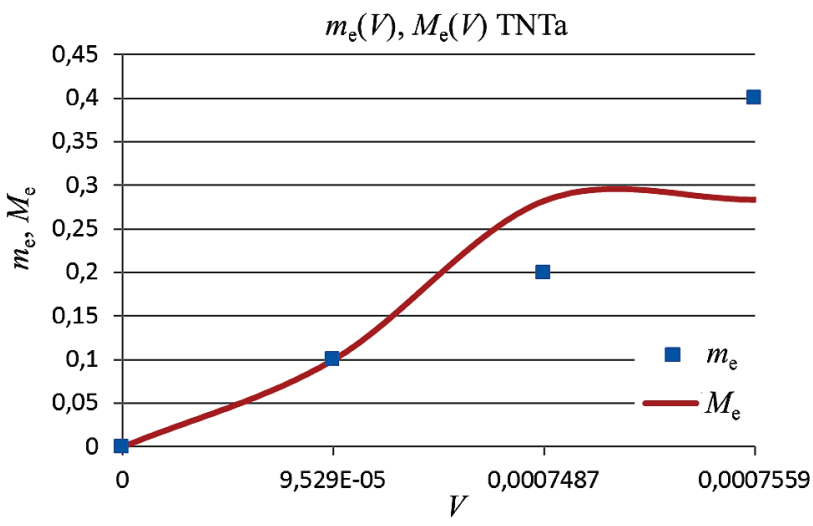

Figure 5 The experimental $m_{\mathrm{e}}\left(V_{\mathrm{k}}\right)$ and calculated dependence $M_{\mathrm{e}}\left(V_{\mathrm{k}}\right)$

The relation of dependence of the mass of explosive used, crater volume and contact area between the explosive charge and the asphalt surface was shown by the experiments and it would be as follows

$M_{\mathrm{e}}=617,952 V_{\mathrm{k}}^{0,794} P_{\mathrm{k}}^{0,309}$,

where $M_{\mathrm{e}}(\mathrm{kg})$ is the mass of explosive used (TNT equivalent), $V_{\mathrm{k}}\left(\mathrm{m}^{3}\right)$ is the crater volume and $P_{\mathrm{k}}\left(\mathrm{m}^{2}\right)$ is contact area between the explosive charge and the asphalt surface.

When one does the estimation of explosive mass using empirical equations, the deviations of true values of the explosive charge mass $m_{\mathrm{e}}(\mathrm{kg})$ in relation with the values of mass $M_{\mathrm{e}}(\mathrm{kg})$ that resulted from calculations with Eqs. (1) $\div$ (9) will be noticed. There are the deviations of true values of the mass of explosive $m_{\mathrm{e}}(\mathrm{kg})$ with which the experiments were performed in relation with the values of mass $M_{\mathrm{e}}(\mathrm{kg})$ that resulted from calculations with Eqs. (1) $\div(9)$. The Eq. (1) gives the deviations in range of $(0,703 \div 0,808)$, the Eq. (2) gives the deviations in range $(1,31 \div 2,43)$. The Eqs. (3) and (4) give the deviations in ranges of $(0,926 \div 0,950)$ and $(0,825 \div 0,883)$. The Eq. (5) gives the deviations in range $(0,331 \div 0,729)$. The Eq. (6) gives the deviations in range $(0,327 \div 0,553)$. The Eq. (7) gives the greatest deviations $\left(10^{3}\right)$. During the analysis of function of the explosive mass and crater diameter dependence which is given with (7) we find that with rise of crater diameter till the value of $d_{\mathrm{c}}=4,5891 \mathrm{~m}$ the explosive mass will decrease. As all those diameters in experiments are less than that value, this equation is not usable for small explosions. The Eq. (8) gives the deviations in range $(0,795 \div 0,996)$ and the Eq. (9) gives the deviations almost $100 \%(0,978 \div$ 0,991).

\section{Conclusion}

Theoretical considerations and experimental studies have shown that the level of damage to the surface in the form of a crater is in the functional dependence of: mass and type of the explosive charge and the place of explosive's initiation. Based on the experimental data it can be concluded that the shape and size of the base of a crater largely depend on the shape and size of the contact area between the explosive charge and the surface, with which the initial hypothesis is confirmed. The crater dimensions are highly influenced by the size of the contact area of the explosive charge and the surface. If the contact area is greater, the calculated explosive mass will be greater.

The suggested equations can be used for the prediction of crater characteristics (dimensions of the crater - the diameter and the depth of the crater and the crater volume) in surface explosions of known charges on asphalt surface. The obtained experimental results indicate the dependence of emerged effects of the explosion (craters) and starting values (type of explosive, mass, way of placement and way of initiation), so these can be used for the estimation of the explosive charge mass that caused the explosion. The estimation of the mass of explosive used could be made with the use of comparison method - comparison of parameters in the concrete case with the parameters of experimentally performed explosions. Of course, if the Eq. (10) is used for the estimation of explosive charge mass based on crater characteristics on asphalt, the most reliable results will be got. Also, suggested Eqs. (10) and (11) can be used for the predictions of dimensions of a crater on asphalt if the explosive mass is known. The mass of explosive used can be calculated with suggested equations and TNT equivalent for the explosive used. During the bomb scene investigation it is implied that forensic chemists already did the analysis of samples from the crater and determined the type of explosive.

\section{Acknowledgements}

The authors are most grateful to all participants who took part in this work, especially to Ljubodrag Klikovac who helped with experiments and Maja Živanović and Vesna Andjelić Nikolendžić who provided language help.

\section{References}

[1] Kennedy, P. M.; Kennedy, J. Explosion Investigation and Analysis-Kennedy on Explosions. Investigations Institute, Chicago, Illinois, 1990.

[2] Korajlić, N. Criminalistic methodology of discovering and proofing of explosions. Centre for security studies, Sarajevo, 2009.

[3] Žarković, M.; Bjelovuk, I. D.; Kesić, T. Crime Scene Management and Credibility of Scientific Evidence. Academy of Criminalistic and Police Studies, Belgrade, 2012.

[4] Cooper, P. Explosive'sEngineering. Wiley-VCH, New York, 1997.

[5] Szuladzinsky, G. Formulas for Mechanical and Structural Shock and Impacts. CRC Press, Boca Raton, 2010.

[6] Jaramaz, S. Physics of explosion. University of Belgrade, Mechanical Engineering Faculty, Belgrade, 1997.

[7] Bjelovuk, I. D. Forensic characterization of traces and effects on the surroundings after an explosion of high (brisant) explosives, Master Thesis, Faculty of Mechanical Engineering, Belgrade University, 2005.

[8] Recovery of Material from the Scene of an Explosion and its Subsequent Forensic Laboratory Examination - a Team 
Approach. // Forensic Investigation of Explosions / Aleksander Beveridge. New York: Taylor \& Fransis, 1998, pp. 101-129.

[9] Explosion. // Lees' Loss prevention in the process industries: Hazard Identification, Assessment and Control / Sam Mannan, Lees Frank. Oxford: Butterworth Heinemann, 1996, pp. 17/1-17/326.

[10] Bjelovuk, I. D. Analysis of the traces after the explosion of an unknown device. // Bezbednost. 47, 2(2005), pp. 302310.

[11] Ambrosini, R. D.; Luccioni, B. M.; Danesi, R. F.; Riera, J. D.; Rocha, M. M. Size of craters produced by explosive charges on or above the ground surface. // Shock Waves, 12, 1(2002), pp. 69-78.

[12] Bjelovuk, I. D.; Jaramaz, S.; Mickovic, D. Estimation of explosive charge mass used for explosions on concrete surface for the forensic purpose. // Science and Justice. 52, 1(2012), pp. 20-24.

[13] Zhang, Y-Q.; Hao, H.; Lu, Y. Anisotropic dynamic damage and fragmentation of rock materials under explosive loading. // International Journal of Engineering Science. 41, 9(2003), pp. 917-929.

[14] Merrifield, R. Fire and explosion hazards to flora and fauna from explosives. // Journal of Hazardous Materials. 74, 3(2000), pp. 149-161.

[15] Luccioni, B. M.; Ambrosini, R. D. Numerical assessment of blast effects scaling procedures. // Mecanica Computacional. 29, (2010), pp. 1161-1179.

[16] Draganić, H.; Sigmund, V. Blast loading on structures. // Tehnicki vjesnik-Technical Gazette. 19, 3(2012), pp. 643652.

[17] Ivanov, B. A. Complex Crater Formation: Verification of Numerical Models, Results of the Workshop on Impact Cratering: Bridging the Gap between Modeling and Observations. 2003. http://www.lpi.usra.edu/publications/ reports/CB-1162/CB-1162-fullreport.pdf (22.08.2012).

[18] Holsapple, Keith A. Crater Sizes from Explosions and Impacts. http://keith.aa.washington.edu/craterdata/scaling/ index.htm (30.09.2011).

\section{Authors' addresses}

Ivana D. Bjelovuk, MSc, M Eng, lecturer

Academy of Criminalistic and Police Studies

Cara Dušana 196, 11080 Belgrade - Zemun, Serbia

E-mail: ivana.bjelovuk@kpa.edu.rs

Slobodan Jaramaz, PhD, M Eng, Full Professor

University of Belgrade, Faculty of Mechanical Engineering,

Kraljice Marije 16, 11000 Belgrade, Serbia

E-mail: sjaramaz@mas.bg.ac.rs

Predrag Elek, PhD, M Eng, Associated Professor

University of Belgrade, Faculty of Mechanical Engineering,

Kraljice Marije 16, 11000 Belgrade, Serbia

E-mail: pelek@mas.bg.ac.rs

Dejan Micković, PhD M Eng, Associated Professor

University of Belgrade, Faculty of Mechanical Engineering,

Kraljice Marije 16, 11000 Belgrade, Serbia

E-mail: dmicković@mas.bg.ac.rs

Lazar Kričak, PhD MG Eng, Full Professor

University of Belgrade, Faculty of Mining and Geology,

Djušina 7, 11000 Belgrade, Serbia

E-mail: kricak@rgf.bg.ac.rs 